\title{
Impact of Body Mass Index on Blood Pressure Levels in Patients with Polycystic Ovary Syndrome
}

\section{artigo original}

\author{
CRISTIANO R.G. BARCELLOS \\ MICHELLE P. ROCHA \\ SYLVIA A.Y. HAYASHIDA \\ DÉCIO MION JUNIOR \\ SILVIA G. LAGE \\ José A.M. MARCONDES
}

Endocrinology Unit (CRGB, MPR

\& JAMM), Gynecology Unit

(SAYH), Hypertension Unit (DMJr), and Heart Institute (SGL), Hospital das Clínicas, Faculdade de Medicina da Universidade de São Paulo, SP.

Recebido em 09/10/06 Aceito em 17/04/07

\section{ABSTRACT}

As there is controversy about the prevalence of hypertension in patients with polycystic ovary syndrome (PCOS) and, up to the present moment, no studies have evaluated the impact of body mass index (BMI) on blood pressure levels (BP) in these patients, we studied retrospectively sixty-nine patients with PCOS, with $\mathrm{BMI}$ of $29.0 \pm 6.7 \mathrm{~kg} / \mathrm{m}^{2}$ and aged $25.6 \pm 5.6 \mathrm{yr}$, subdivided into three groups according to BMI (normal, overweight and obese) and evaluated regarding BP (mercury sphygmomanometer), basal hormonal profile, fasting glucose, and insulin sensitivity (HOMA-IR). Mean systolic blood pressure (SBP) and diastolic blood pressure (DBP) were normal $(118.1 \pm 17.0$ and $74.7 \pm 11.5 \mathrm{mmHg}$, respectively), with a hypertension prevalence of $20.3 \%$. Of these patients, $78.6 \%$ were obese and $21.4 \%$ were overweight. When the groups were compared according to $\mathrm{BMI}$, a significant increase in SBP and DBP was observed (higher in overweight and obese patients for SBP and higher in obese for DBP), as well as a significant progressive increase in glucose, insulin, homeostatic model assessment, and a significant progressive decline in LH levels. When the patients were subdivided as normotensive or hypertensive, a significant difference was observed only for BMI $\left(28.2 \pm 6.1\right.$ and $34.7 \pm 8.6 \mathrm{~kg} / \mathrm{m}^{2}$, respectively; $\left.p=0.007\right)$. In conclusion, we observed a significant and progressive impact of BMI on blood pressure levels in our patients with polycystic ovary syndrome. (Arq Bras Endocrinol Metab 2007;51/7:1104-1109)

Keywords: Polycystic ovary syndrome; Blood pressure levels; Hypertension; Body mass index

\section{RESUMO}

Impacto do Índice de Massa Corporal nos Níveis de Pressão Arterial em Pacientes com Síndrome dos Ovários Policísticos.

Como há controvérsia sobre a prevalência de hipertensão arterial em pacientes com a síndrome dos ovários policísticos (SOP) e, até o momento, nenhum estudo avaliou o impacto do índice de massa corporal (IMC) sobre a pressão arterial (PA), foram estudados retrospectivamente 69 pacientes com a SOP, com IMC de 29,0 \pm $6,7 \mathrm{~kg} / \mathrm{m}^{2}$ e idade de 25,6 $\pm 5,6$ anos, subdivididos em 3 grupos de acordo com o IMC (normal, sobrepeso e obesos) e avaliados com relação à PA, perfil hormonal basal, glicemia de jejum e sensibilidade à insulina (HOMA-IR). As médias das pressões arteriais sistólica (PAS) e diastólica (PAD) foram normais $(118,1 \pm 17,0$ e $74,7 \pm 11,5 \mathrm{mmHg}$, respectivamente), com uma prevalência de hipertensão de $20,3 \%$. Das pacientes hipertensas, $78,6 \%$ eram obesas e $21,4 \%$ apresentavam sobrepeso. Quando os grupos, subdivididos de acordo com o IMC, foram comparados, aumento significativo da PAS e PAD foi observado (PAS maior nas pacientes com sobrepeso e obesas e PAD maior nas pacientes obesas), assim como um aumento progressivo da glicemia, insulina e HOMA-IR, e um decréscimo significante e progressivo de LH. Quando as pacientes foram subdivididas em normotensas e hipertensas, diferença significativa foi observada somente para IMC $\left(28,2 \pm 6,1\right.$ e $34,7 \pm 8,6 \mathrm{~kg} / \mathrm{m}^{2}$, respectivamente; $\left.\mathrm{p}=0,007\right)$. Em conclusão, observamos um impacto significativo e progressivo do IMC sobre os níveis pressóricos em nossas pacientes com a síndrome dos ovários policísticos. (Arq Bras Endocrinol Metab 2007;51/7:1104-1109)

Descritores: Síndrome dos ovários policísticos; Pressão arterial; Hipertensão; Índice de massa corporal 
$\mathrm{T}$ HE POLYCYSTIC OVARY SYNDROME (PCOS) is a heterogeneous disorder, characterized by chronic anovulation and hyperandrogenism, affecting approximately $5 \%$ to $10 \%$ of women in reproductive age (1). It is considered a complex metabolic disease and a risk factor for the development of diabetes mellitus (DM), heart disease, and endometrial cancer (2-4). Insulin resistance (IR) has been considered to be the linkage between the carbohydrate metabolism disorder and the increased risk of cardiovascular events and PCOS (5).

Similarly, hypertension can be considered as one of IR manifestations. Subjects with idiopathic hypertension show a significant decrease in insulin sensitivity $(6,7)$. A link between hypertension and IR, regardless of the presence of obesity, was initially proposed by Osei, in 1999 (8). Others factors that can influence blood pressure levels are age and body mass index $(\mathrm{BMI})(9,10)$, which are also related with IR $(11,12)$.

Menopausal women who previously underwent wedge resection of the ovary for PCOS treatment showed a prevalence of hypertension three times higher than healthy women (13). A higher incidence of hypertension was also observed in perimenopausal women with PCOS compared to a group of control women (14), but not by Cibula et al., in perimenopausal women also (15). In all these studies, control group was pairwise matched for age and weight.

For PCOS patients at reproductive age, the prevalence of hypertension was significantly higher than that observed in control group, varying from $9 \%$ to $22 \%(14,16)$. Considering blood pressure levels, it has been observed without significant differences $(17,18)$, significant higher systolic and diastolic blood pressure (DBP) (16) as well as significant higher casual diurnal systolic blood pressure (SBP) (19) when compared with control group.

Only one study reported the effect of age and BMI on the prevalence of hypertension in patients with PCOS, but not on blood pressure levels (14). The aim of this study was to evaluate the impact of BMI on blood pressure levels in patients with PCOS.

\section{PATIENTS AND METHODS}

All patients registered as having PCOS in the out-patient hirsutism clinic of the Endocrine Unit of Hospital das Clínicas of São Paulo, from 1995 to 2004, were traced retrospectively. The patients had been referred to the clinic for hirsutism evaluation, and PCOS diagnosis was based on the presence of hirsutism and menstrual dysfunction, after ruling out Cushing's syndrome, non classic 21-hydroxylase deficiency, thyroid dysfunction, hyperprolactinemia, or androgensecreting tumor through adequate testing (20). None of the subjects had any other diseases or had taken any medication for at least 6 months.

Blood pressure (BP) was measured twice in a mercury sphygmomanometer with cuffs that were adequate for the circumference of the patient's arm. The patients were in the supine position after a 20 -minute rest period. We considered hypertension when SBP was equal to or higher than $140 \mathrm{mmHg}$ and/or DBP was equal to or higher than 90 $\mathrm{mmHg}$ for diastolic BP, in accordance with the IV Brazilian Guidelines in Arterial Hypertension (21). Body mass index (BMI) was calculated by the formula: weight $(\mathrm{kg}) /$ height (meters) $)^{2}$.

The patients were subdivided into groups, according to BMI (normal weight: 18.5 to $24.9 \mathrm{~kg} / \mathrm{m}^{2}$; overweight: 25.0 to $29.9 \mathrm{~kg} / \mathrm{m}^{2}$; obese: $\geq 30 \mathrm{~kg} / \mathrm{m}^{2}$ ), blood pressure levels (normotensive and hypertensive), and age (less and higher the mean).

Insulin resistance (IR) was measured through the homeostatic model assessment (HOMA-IR), calculated as follows: fasting glucose $(\mathrm{mmol} / \mathrm{L}) \mathrm{x}$ fasting insulin $(\mu \mathrm{UI} / \mathrm{mL}) / 22.5$.

After an overnight fast, blood samples were obtained from an antecubital vein for the determination of glucose, insulin, testosterone, dehydroepiandrosterone sulphate (DHEAS), progesterone, luteinizing hormone (LH), and follicle-stimulating hormone (FSH), regardless of the last menstruation date. Samples were considered only when progesterone concentration was lower than $3 \mathrm{ng} / \mathrm{mL}$ (22).

Plasma glucose concentration was determined by a glucose oxidase method.

For hormone assay determination, blood samples were centrifuged, and serum was stored at $-20^{\circ} \mathrm{C}$ until assayed.

Progesterone and testosterone were measured by fluoroimmunometric assay (Wallac, Finland). Insulin, LH, and FSH were measured by immunofluorometric assay (Wallac, Finland) and DHEAS were measured by radioimmunoassay (Cisbio International, France, and DSL, Texas, USA).

All the assays were performed in duplicate and the intra-assay and interassay coefficients of variation did not exceed $10 \%$ and $15 \%$, respectively.

\section{Statistical analysis}

The Kolmogorov-Smirnov test was performed in order to evaluate the normal distribution of variables. The results were expressed as mean \pm standard deviation $(\mathrm{SD})$. The comparison between the groups with different BMI was carried out through analysis of variance (ANOVA) test for variables with normal distribution and Tukey-Kramer test for analysis of multiple comparisons. For the nonparametric variables, the comparison between the groups was performed through Kruskal-Wallis test and the contrast test used was the MullerDunn's. Correlation analysis between BP levels and BMI and insulin sensitivity parameters (insulin and HOMA-IR) were carried out through linear correlation of Pearson. 
Comparison between the groups of normotensive and hypertensive patients and less and higher of the mean of age was performed by the t-Student test. Values of $\mathrm{p}<0.05$ were considered statistically significant.

\section{RESULTS}

Sixty-nine patients, with BMI of $29.0 \pm 6.7 \mathrm{~kg} / \mathrm{m}^{2}$ and aged $25.6 \pm 5.6 \mathrm{yr}$, met the adopted criteria for PCOS. All of them presented menstrual abnormalities and hirsutism. The mean SBP and DBP were normal $(118.1 \pm 17.0$ and $74.7 \pm 11.5 \mathrm{mmHg}$, respectively).

Regarding BMI, eighteen patients (26.1\%) were normal, $19(27.5 \%)$ were overweight and 32 (46.4\%) were obese, without significant difference regarding age among them (24.4 yr, $24.6 \mathrm{yr}$ and $27.0 \mathrm{yr}$, respectively; $\mathrm{p}=0.160$ ). As can be seen in table $\mathrm{l}$ and figure 1 , SBP was significantly higher in the groups of overweight and obese patients than in the normal BMI group $(\mathrm{p}=$ 0.001 and $<0.001$, respectively), without any significant difference between them $(\mathrm{p}=0.636)$. For DBP, it was significantly higher in the groups of obese than in the normal and overweight groups $(\mathrm{p}<0.001$ and $\mathrm{p}<$ 0.05 , respectively), without any significant difference between the normal and overweight groups $(\mathrm{p}>0.05)$.

When the laboratory parameters were analyzed according to BMI (table 1), there was a progressive and significant decrease in LH level from normal weight to obese groups and a progressive and significant increase of glucose, insulin, and HOMA-IR from normal weight to obese groups. The mean of LH levels was significantly lower and the mean of glucose, insulin, HOMA-IR, SBP, and DBP were significantly higher in obese versus normal weight groups, while the mean of LH was significantly lower and the mean of HOMA-IR and DBP were significantly higher in obese versus overweight groups. When the group of normal weight and overweight were compared, there were significant differences only for the mean of LH levels, lower in overweight group, and for the mean of SBP levels, higher in overweight group.

The prevalence of hypertension in the group as a whole was $20.3 \%(n=14)$. Four patients showed isolated systolic hypertension and four showed isolated diastolic hypertension, while the other six showed both systolic and diastolic hypertension. When the patients were subdivided according to the mean of age, an $18.2 \%$ hypertension prevalence was observed in those younger than 25.6 years of age $(n=33)$, rising to $21.0 \%$ when above this age range $(n=36)$. The mean level of SBP and DBP for the group younger than 25.6 yr were $117.4 \pm 18.5 ; 73.4 \pm 12.1 \mathrm{mmHg}$, respectively, while for the group older than $25.6 \mathrm{yr}$ were $118.3 \pm 15.8 ; 75.6 \pm 11.1 \mathrm{mmHg}$, respectively, without significant difference between them $(\mathrm{p}=$ 0.840 for $\mathrm{SBP}$ and $\mathrm{p}=0.441$ for $\mathrm{DBP}$ ).

Regarding BMI, $78.6 \%$ of the hypertensive patients were obese and $21.4 \%$ were overweight. No patients with normal BMI were hypertensives.

When the group of normotensive patients was compared with the group of hypertensive patients, a significant difference was observed only for BMI, higher in the group of hypertensive patients $28.2 \pm 6.1$ $\mathrm{kg} / \mathrm{m}^{2}$ persus $34.7 \pm 8.6 \mathrm{~kg} / \mathrm{m}^{2}, \mathrm{p}=0.007$ ) (table 2 ).

Body mass index was positive correlated with $\operatorname{SBP}(\mathrm{r}=0.4494 ; \mathrm{p}<0.001)$ and DBP $(\mathrm{r}=0.5829 ; \mathrm{p}$ $<0.001)$. We did not observe correlation between BP levels (SBP and DBP) and insulin sensitivity parameters, insulin, and HOMA-IR.
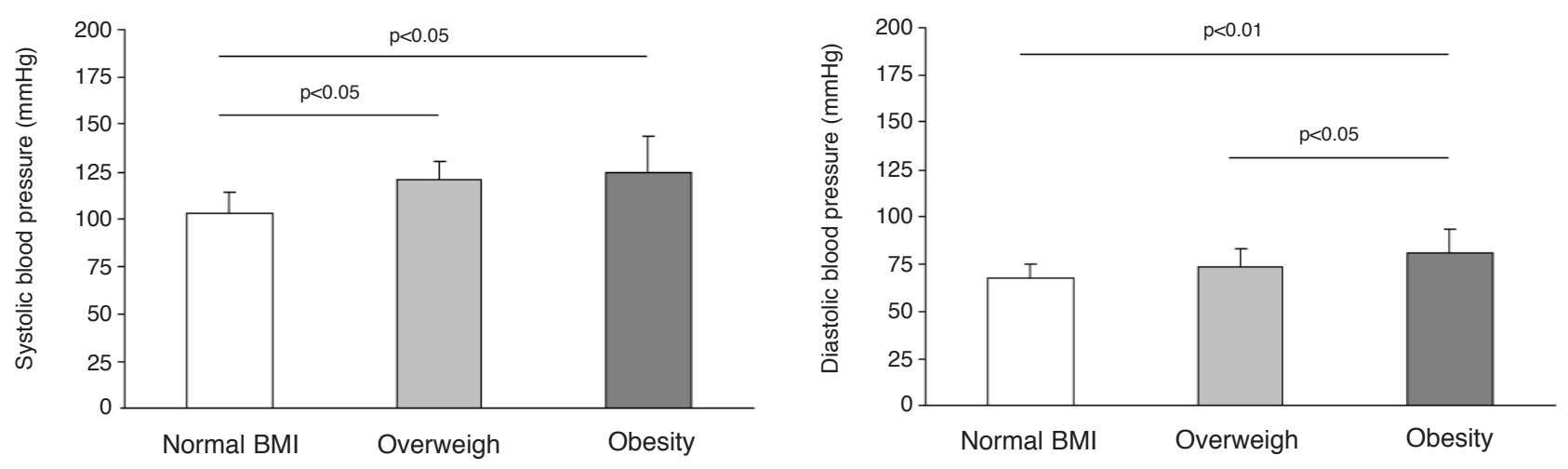

Figure 1. Systolic (upper panel) and diastolic (lower panel) blood pressure means according to body mass index (BMI) in patients with polycystic ovary syndrome. 
Table 1. Laboratory and clinic profile, under basal conditions, according to body mass index.

\begin{tabular}{lcccc}
\hline & $\begin{array}{c}\text { Normal } \\
(\mathbf{n}=\mathbf{1 8})\end{array}$ & $\begin{array}{c}\text { Overweight } \\
(\mathbf{n}=\mathbf{1 9 )}\end{array}$ & $\begin{array}{c}\text { Obese } \\
(\mathbf{n}=\mathbf{3 2})\end{array}$ & $\begin{array}{c}\mathbf{p} \\
\text { (ANOVA or } \\
\text { Kruskal-Wallis) }\end{array}$ \\
$\mathrm{LH}^{1}(\mathrm{IU} / \mathrm{liter})$ & $14.4 \pm 6.6$ & $11.1 \pm 4.4^{\mathrm{a}}$ & $8.2 \pm 3.7^{\mathrm{b}, \mathrm{c}}$ & $<0.001$ \\
$\mathrm{FSH}^{1}(\mathrm{IU} / \mathrm{liter})$ & $5.3 \pm 1.8$ & $4.9 \pm 1.9$ & $5.2 \pm 2.6$ & 0.807 \\
Testosterone $^{1}(\mathrm{ng} / \mathrm{dl})$ & $119.6 \pm 45.1$ & $119.5 \pm 36.0$ & $118.6 \pm 42.4$ & 0.995 \\
DHEAS $^{1}(\mathrm{ng} / \mathrm{ml})$ & $1,920.3 \pm 1,163.0$ & $2,816.8 \pm 1,948.7$ & $1,901.2 \pm 1,170.1$ & 0.066 \\
Glucose $^{1}(\mathrm{mg} / \mathrm{dl})$ & $82.3 \pm 8.2$ & $89.5 \pm 9.0$ & $92.7 \pm 13.4^{\mathrm{b}}$ & 0.008 \\
Insulin $^{2}(\mu \mathrm{lU} / \mathrm{ml})$ & $10.2 \pm 8.1$ & $20.7 \pm 14.3$ & $33.1 \pm 18.6^{\mathrm{d}}$ & $<0.0001$ \\
$\mathrm{HOMA}^{-\mathrm{R}^{2}}$ & $2.1 \pm 1.5$ & $4.4 \pm 3.1$ & $7.6 \pm 3.9^{\mathrm{c}, \mathrm{d}}$ & $<0.0001$ \\
$\mathrm{SBP}^{1}(\mathrm{mmHg})$ & $103.3 \pm 10.3$ & $120.8 \pm 9.8^{\mathrm{a}}$ & $124.7 \pm 18.4^{\mathrm{b}}$ & $<0.001$ \\
$\mathrm{DBP}^{1}(\mathrm{mmHg})$ & $67.4 \pm 7.3$ & $73.4 \pm 9.5$ & $80.9 \pm 12.4^{\mathrm{c}, \mathrm{d}}$ & 0.0002 \\
\hline
\end{tabular}

Values expressed in mean \pm SD. Comparison between the groups performed through ANOVA test and Tukey-Kramer test for multiple comparisons.

Values expressed in mean \pm SD. Variance analysis performed through Kruskal-Wallis test and multiple comparison by pairs through Dunn method.

a $\mathrm{p}<0,05$ Normal weight versus Overweight; $\mathrm{b}_{\mathrm{p}} \mathrm{p}<0,05$ Normal weight versus Obese; ${ }^{\mathrm{c}} \mathrm{p}<0,05$ Overweight versus Obese; $\mathrm{d} p<0.001$ Normal weight versus obese.

LH: luteinizing hormone; FSH: follicle-stimulating hormone; DHEAS: dehydroepiandrosterone sulphate; HOMA-IR: homeostatic model assessment; SBP: systolic blood pressure; DBP: diastolic blood pressure.

Table 2. Comparison of clinical and laboratory parameters between the groups of normotensive and hypertensive patients ${ }^{1}$.

\begin{tabular}{lccc}
\hline & $\begin{array}{c}\text { Normotensives } \\
(\mathbf{n}=\mathbf{5 5})\end{array}$ & $\begin{array}{c}\text { Hypertensives } \\
(\mathbf{n}=\mathbf{1 4})\end{array}$ & $\mathbf{p}$ \\
$\mathrm{Age}^{2}(\mathrm{years})$ & $25.9 \pm 5.5$ & $24.4 \pm 6.8$ & 0.47 \\
$\mathrm{BMI}^{2}\left(\mathrm{~kg} / \mathrm{m}^{2}\right)$ & $28.2 \pm 6.1$ & $34.7 \pm 8.6$ & 0.007 \\
$\mathrm{LH}^{2}(\mathrm{IU} / \mathrm{liter})$ & $10.7 \pm 5.7$ & $10.9 \pm 3.3$ & 0.91 \\
$\mathrm{FSH}^{2}(\mathrm{IU} / \mathrm{liter})$ & $5.1 \pm 2.3$ & $5.7 \pm 1.8$ & 0.46 \\
$\mathrm{Testosterone}^{2}(\mathrm{ng} / \mathrm{dl})$ & $118.9 \pm 37.0$ & $135.9 \pm 54.9$ & 0.23 \\
DHEAS $^{2}(\mathrm{ng} / \mathrm{ml})$ & $2,156.1 \pm 1,523.3$ & $2,420.1 \pm 1,238.3$ & 0.62 \\
$\mathrm{Glucose}^{2}(\mathrm{mg} / \mathrm{dl})$ & $88.9 \pm 12.4$ & $88.0 \pm 8.2$ & 0.83 \\
Insulin $^{3}(\mu \mathrm{lU} / \mathrm{ml})$ & $21.6 \pm 17.9$ & $29.0 \pm 15.0$ & 0.08 \\
$\mathrm{HOMA}^{2}$ & $5.18 \pm 4.07$ & $5.15 \pm 3.62$ & 0.98 \\
\hline
\end{tabular}

BMI: body mass index; LH: luteinizing hormone; FSH: follicle-stimulating hormone; DHEAS: dehydroepiandrosterone sulphate; HOMA-IR: homeostatic model assessment.

${ }^{1}$ According to the IV Brazilian Guidelines in Arterial Hypertension (21).

2 Values expressed in mean \pm SD. Comparison between groups performed through t-Student test.

3 Values expressed in mean \pm SD. Comparison between groups obtained through Mann-Whitney test.

\section{DISCUSSION}

The prevalence of hypertension in patients with PCOS varies according to the age range of the patients. For menopausal or climacteric women with a previous history of PCOS, this prevalence varies from $28.1 \%$ to $39.0 \%(13,14)$, while for patients who are in their third or fourth decades of life, the prevalence varies from $3.8 \%$ to $22.0 \%(14,16)$. This difference of prevalence according to the age range is probably a conse- quence of aging itself, as the studied patients were pairwise matched by weight and, as shown in the study of Elting et al., the prevalence of hypertension increased significantly with the age range (14). In our series, in patients who are in the second to the third decades of life, the prevalence was $20.3 \%$, similar to the one observed by Vrbíková et al., of $22 \%$, in the same age range and using the same methodology (mercury sphygmomanometer reading) (16), but higher than that observed by Elting et al. in this same 
age range $(3.8 \%)$ (14), possibly due to the methodology used by them (telephone inquiry), which might have underestimated the real prevalence of BP.

Our prevalence was similar to the one observed in the general population of the city of São Paulo by Rego et al. (23), of $22 \%$, but lower than that observed by Mion et al. (10), of 26\%, among employees who work in the healthcare area of the same city. However, when our patients were subdivided according to the mean of age, the prevalence of hypertension in the ones younger than 25.6 yr was $18.2 \%$, and $21.0 \%$ in those older than this age, which is higher than the one observed by Mion et al. in the same age range (10), being $8 \%$ in those younger than $30 \mathrm{yr}$ and $17 \%$ in those between 31 and 40 years of age.

Considering that $\mathrm{BMI}$ is a determinant factor of pressure levels (24), we subdivided our patients into three groups (normal weight, overweight, and obese) in order to evaluate the BMI impact on the prevalence of hypertension. We observed that the prevalence of hypertension increased with BMI. In fact, no patient with normal BMI showed hypertension, while 21.4\% of patients with hypertension were overweight and $78.6 \%$ were obese. According to these, when hypertensive patients were compared with normotensive ones, a significant difference was observed only for BMI, which was higher in hypertensive patients. Moreover, we showed a positive correlation between $\mathrm{BP}$ levels and BMI. The influence of BMI on the prevalence of hypertension in patients with PCOS was the object of study only of Elting et al, which found a higher BP prevalence for a BMI > $27 \mathrm{~kg} / \mathrm{m}^{2}$ (14).

We also observed a BMI impact on LH concentrations and on the parameters related to insulin sensitivity. In fact, LH concentrations and insulin sensitivity decreased, while the glucose and insulin concentrations augmented with BMI increase. These data are compatible with those found in the literature (25), and they could be indicating a worsening of the parameters relative to the carbohydrate metabolism with the increase of the BMI and a possible modulation of LH secretion by insulin (26).

In the general population, a positive correlation between blood pressure levels and plasma insulin concentrations has been observed (27-30), while in essential hypertension, insulin resistance, regardless of obesity, has been demonstrated in subjects with normal glucose tolerance $(6,27)$. In this study, we observed that blood pressure levels and the prevalence of hypertension increased and insulin sensitivity decreased, while there was a BMI increase. However, when the group of normotensive patients was compared with the hypertensive ones, an issue not yet addressed in previous studies (17-19), we did not observe significant difference with relation to insulin sensitivity. Moreover, we did not observe correlation between BP levels and insulin sensitivity parameters. In fact, the relationship between insulin sensitivity and blood pressure levels in PCOS is controversial. Zimmerman et al. (17) and Sampson et al. (18) did not find differences in blood pressure levels when using $24 \mathrm{~h}$ blood pressure measurement between normal and PCOS women, although a significant difference with relation to insulin sensitivity was observed. We believe that there are other determinants of hypertension in our patients with PCOS, such as genetic predisposition, among others. According to Elting et al. (14), hypertensive patients with PCOS have a higher prevalence of familial hypertension than the ones with PCOS without hypertension, suggesting genetically distinct populations.

In conclusion, we observed that the prevalence of hypertension increases with BMI and that higher blood pressure levels were associated with higher BMI.

\section{ACKNOWLEDGEMENTS}

We thank Ms. Sonia Strong for the English review.

\section{REFERENCES}

1. Knochenhauser ES, Key TJ, Kahsar-Miller M, Waggoner W, Boots LR, Azziz R. Prevalence of the polycystic ovary syndrome in unselected black and white women of southeastern United States: a prospective study. J Clin Endocrinol Metab 1998;83:3078-82.

2. Rocha MP, Barcellos CRG, Bastos MSC, Hayashida SY, Halbe HW, Marcondes JAM, et al. Prevalência de distúrbios do metabolismo glicídico em pacientes portadoras da síndrome dos ovários policísticos (SOP). Abstract. Arq Bras Endocrinol Metab 2005;49(supl.1):S101.

3. Legro RS. Polycystic ovary syndrome and cardiovascular disease: a premature association? Endoc Rev 2003;24:302-12.

4. Rose PG. Endometrial carcinoma. N Engl J Med 1996;335:640-9.

5. Dunaif A. Insulin resistance and the polycystic ovary syndrome: mechanism and implications for pathogenesis. Endoc Rev 1997;18:774-800.

6. Ferrarini $E$, Buzzigoli $C$, Bonadonna $R$. Insulin resistance in essential hypertension. N Engl J Med 1987;317:350-7.

7. Shen DC, Shieh SM, Wu DA, Reaven GM. Resistance to insulin stimulated glucose uptake in patients with hypertension. J Clin Endocrinol Metab 1988;66:580-3.

8. Osei K. Insulin resistance and systemic hypertension. Am J Cardiol 1999;84:33-6.

9. Papademetriou V. Comparative prognostic value of systolic, diastolic, and pulse pressure. Am J Cardiol 2003;91:433-5.

10. Mion D, Pierin AM, Bambirra AP, Assunção JH, Monteiro JM, Chinen RY, et al. Hypertension in employees of a University General Hospital. Rev Hosp Clin 2004;59:329-36.

11. American College of Obstetricians and Gynecologists Women's Health Care Physicians. Body mass index and insulin resistance. Obstet Gynecol 2004;104(suppl.):5S-10. 
12. Ryan AS. Insulin resistance with aging: effects of diet and exercise. Sports Med 2000;30:327-46.

13. Dalghren E, Johansson S, Lindstedt G, Knutsson F, Odén A, Jansen PO, et al. Women with polycystic ovary syndrome wedge resected in 1956 to 1965: a long-term follow-up focusing on natural history and circulating hormones. Fertil Steril 1992;57:505-13.

14. Elting MW, Korsen TJM, Bezemer PD, Schoemaker J. Prevalence of diabetes mellitus, hypertension and cardiac complaints in a follow-up study of a Dutch PCOS population. Hum Reprod 2001; 16:556-660.

15. Cibula D, Cífková R, Fanta M, Poledne R, Zivny J, Skibová J. Increased risk of non-insulin dependent diabetes mellitus, arterial hypertension and coronary artery disease in perimenopausal women with a history of the polycystic ovary syndrome. Hum Reprod 2000;15:785-9.

16. Vrbíková J, Cífková R, Jirkovská A, Platilová H, Zamrazil V, Stparka L. Cardiovascular risk factors in young Czech females with polycystic ovary syndrome. Hum Reprod 2003;18:980-

17. Zimmermann S, Phillips RA, Dunaif A, Finegood DT, Wilkenfeld C, Ardeljan M, et al. Polycystic ovary syndrome: Lack of hypertension despite profound insulin resistance. J Clin Endocrinol Metab 1992;75:508-13.

18. Sampson M, Kong C, Patel A, Unwin R, Jacobs HS. Ambulatory blood pressure profiles and plasminogen activator inhibitor (PAI-1) activity in lean women with and without the polycystic ovary syndrome. Clin Endocrinol 1996;45:623-9.

19. Holte J, Gennarelli G, Berne C, Bergh T, Lithell H. Elevated ambulatory day-time blood pressure in women with polycystic ovary syndrome: a sign of a pre-hypertensive state? Hum Reprod 1996;11:23-8.

20. Zawadzki JK, Dunaif A. Diagnostic criteria for polycystic ovary syndrome: towards a rational approach. In: Dunaif $A$, Givens JR, Haseltine FP, Merriam GR (eds). Polycystic ovary syndrome. Oxford: Blackwell Scientific, 1992. pp. 377-84.

21. IV Brazilian Guidelines in Arterial Hypertension. Arq Bras Cardiol 2004;82(suppl. 4):7-22.

22. Legro RS, Chiu P, Kunselman AR, Bentley CM, Dodson WC Dunaif A. Polycystic ovaries are common in women with hyperandrogenic chronic anovulation but not predict metabolic or reproductive phenotype. J Clin Endocrinol Metab 2005;90:2571-9.
23. Rego RA, Berardo FA, Rodrigues SS, Oliveira ZM, Oliveira $M B$, Vasconcellos $C$, et al. Risk factors for chronic non-communicable diseases: a domiciliary survey in the municipality of São Paulo, SP (Brazil). Methodology and preliminary results. Rev Saúde Pública 1990;24:277-85.

24. Gus M, Moreira LB, Pimentel M, Gleisener AL, Moraes RS, Fuchs FD. The association between different measurements of obesity and the prevalence of hypertension. Arq Bras Cardiol 1998:70:111-4.

25. Vrbíková J, Cibula D, Dvoráková K, Stanická S, Sindelka G, Hill $M$, et al. Insulin sensitivity in women with polycystic ovary syndrome. J Clin Endocrinol Metab 2004;89:29425.

26. Dorn C, Mouillet JF, Yan X, Ou Q, Sadovsky Y. Insulin enhances the transcription of luteinizing hormone-beta gene. Am J Obstet Gynecol 2004;191:132-7.

27. Pollare T, Lithell H, Berne C. Insulin resistance is a characteristic feature of a primary hypertension independent of obesity. Metabolism 1990;39:167-74.

28. Modan M, Halkin H, Almog S, Lusky A, Eshkol A, Shefi M, et al. Hyperinsulinemia: a link between hypertension, obesity, and glucose tolerance. J Clin Invest 1985;75:809-17.

29. Zavaroni I, Bonora E, Pagliara M, Dall'Aglio E, Luchetti L, Buonanno $G$, et al. Risk factors for coronary artery disease in healthy persons with hyperinsulinemia and normal glucose tolerance. N Engl J Med 1989;320:702-6.

30. Natali A, Santoro D, Palombo C, Cerri M, Ghione S, Ferrannini $E$. Impaired insulin action skeletal muscle metabolism in essential hypertension. Hypertension 1991;17:170-8.

\section{Endereço para correspondência:}

José Antonio Miguel Marcondes

Rua Baronesa de Itu 821, apto. 112

01231-001 São Paulo, SP

E-mail: marcondesmd@uol.com.br 